\title{
Immune Islet Killing Mechanisms Associated with Insulin-Dependent Diabetes: Three Rabbit Antibody-Mediated Islet Cell Cytotoxicity Models
}

\author{
M.A.Charles ${ }^{1,2}$, M. Suzuki ${ }^{1}$, L. Slater ${ }^{1}$, N. Waldeck ${ }^{1}$ and K. Ong ${ }^{3}$ \\ Departments of 'Medicine, ${ }^{2}$ Physiology and ${ }^{3}$ Pediatrics, School of Medicine, University of California, Irvine, California, USA
}

\begin{abstract}
Summary. Antibody-mediated islet cell killing mechanisms have been associated with human insulin-dependent diabetes. Several types of antibody-mediated cytotoxic mechanisms exist, but only complement-dependent antibody-mediated cytotoxicity is reported for islet killing. To evaluate further islet cytotoxic antibody mechanisms, we have studied antibody-dependent cellular cytotoxicity and complement augmented antibody-dependent cellular cytotoxicity using polyclonal rabbit anti-rat islet cell immune serum and ${ }^{51} \mathrm{Cr}$-labelled dispersed normal rat islet target cells. Maximal immune serum-mediated islet cell specific cytotoxicity was $80 \%$ for complement-dependent antibody-mediated cytotoxicity, $40 \%$ for antibody-dependent cellular cytotoxicity and $20 \%$ for complement-augmented antibody-dependent cellular cytotoxicity. The minimum serum dilution for maximal islet cell cytotoxicity was $1: 100$ for complement-dependent antibodymediated cytotoxicity, 1:10 for antibody-dependent cellular cytotoxicity and 1:1000 for complement-augmented antibody-dependent cellular cytotoxicity. These data indicate a
\end{abstract}

unique optimal serum dilution for each of the three antibody killing mechanisms. Immune serum-mediated cytotoxicity was more specific for rat islet target cells than macrophage target cells. That antibody mediated these cytotoxic events was documented using immune serum-derived, DEAE purified immunoglobulin $\mathrm{G}$ which induced killing in all three antibody assays. Both antibody-dependent cellular cytotoxicity assays appear useful for studies of human diabetes, since human non-T mononuclear cells are cytotoxic to islet cells. These results suggest that for studies of potential islet cell killing mechanisms in insulin-dependent diabetes, specific xenogeneic assays exist not only for complement-dependent antibody-mediated islet cytotoxicity, but also for antibody-dependent cellular cytotoxicity and complement augmented antibody-dependent cellular cytotoxicity.

Key words: Islet cell cytotoxicity, complement, antibodies, diabetes.
Immune mechanisms have been implicated in the pathogenesis of Type 1 (insulin-dependent) diabetes [1, 2]. Most reports are of indirect observations, but recent studies have attempted to associate immune mechanisms to human diabetes using complement-dependent antibody-mediated cytotoxicity (C'AMC) assays [3-7]. Cytotoxicity assays in vitro and the reported results vary, but each method described uses islet derived target cells. One report suggests that virtually all sera from Type 1 diabetic patients have C'AMC against cultured rat islet cells, and that sera from non-diabetic parents and siblings also mediated C'AMC [6]. Using intact normal rodent islets or rat or human islet tumour target cells, $10 \%-30 \%$ of patients' sera have C'AMC $[3-5,7]$. Other potential antibody-mediated cytotoxic mechanisms in diabetes have not been examined in detail.

We have developed three relatively simple and reproducible islet specific cytotoxicity assays using noncultured, non-tumour, normal dispersed rat islet target cells. In the studies reported here, a polyclonal rabbit anti-rat islet cell antibody model is used in conjunction with rat islet target cells and human non-T mononuclear effector cells. This model is used to evaluate not only complement-dependent antibody-mediated cytotoxicity (C'AMC), but also antibody-dependent cellular cytotoxicity (ADCC), and complement-augmented antibody-dependent cellular cytotoxicity (C'ADCC). We have found the application of these assays useful in studies of the pathogenesis of human insulin-dependent diabetes as previously described [8].

\section{Subjects and Methods}

\section{Subjects}

Five normal subjects (two women and three men) aged 18 to 32 years understood and signed consent forms. $\Lambda$ ll had normal fasting blood glucose concentrations and none had a family history of diabctes. 


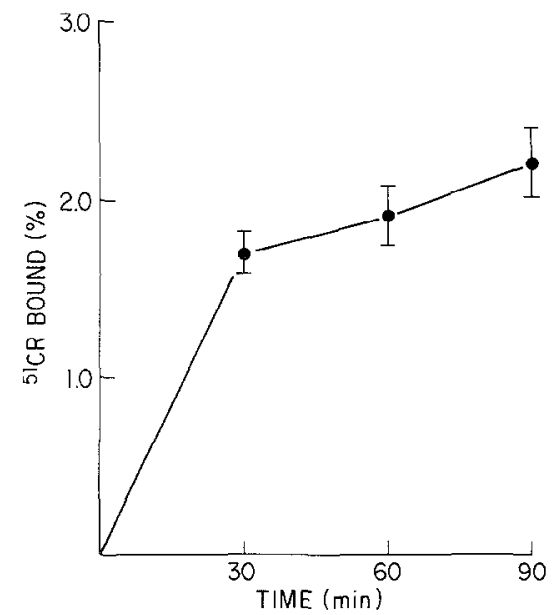

Fig. 1. Time course of ${ }^{51} \mathrm{Cr}$ uptake by dispersed rat islet cells. ${ }^{51} \mathrm{Cr}$ $(50 \mu \mathrm{Ci})$ was incubated with $10^{5}$ islet cells. At $30,60,90 \mathrm{~min}, 2 \times 10^{4}$ cells were removed, washed and the radioactivity estimated. Each data point represents the mean \pm SEM of four separate experiments, using separate target cell preparations on separate days

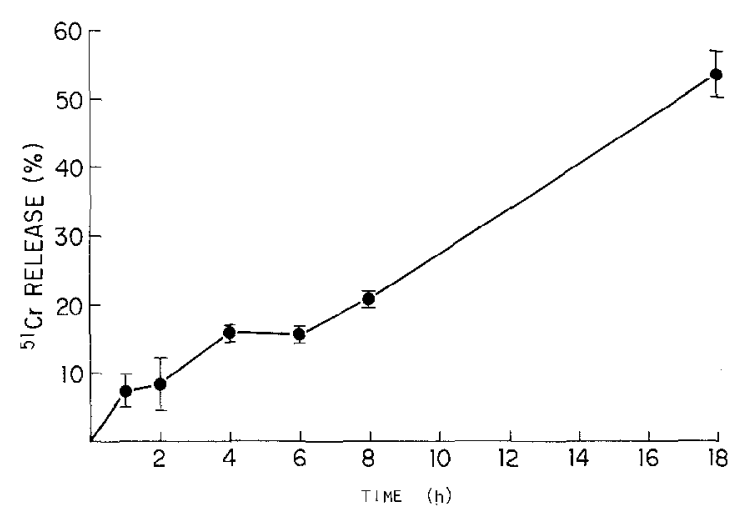

Fig. 2. Spontaneous ${ }^{51} \mathrm{Cr}$ release of dispersed rat islet cells. ${ }^{51} \mathrm{Cr}$-labelled islet cells were incubated, centrifuged and the radioactivity estimated from the supernatants at the times indicated. Data shown are from $n=5$ experiments at $1,2,6$ and $18 \mathrm{~h}, n=28$ at $4 \mathrm{~h}$ and $n=36$ at $8 \mathrm{~h}$ (mean \pm SEM). Each $n$ reflects experiments performed on separate days using separate target cells

\section{Mononuclear Cell Preparation}

Peripheral venous blood from subjects was mixed with 20 units $/ \mathrm{ml}$ of preservative-free heparin (Sigma Chemicals, St. Louis, Missouri). Mononuclear cells were isolated using Ficoll-Hypaque (Pharmacia Fine Chemicals, Piscataway, New Jersey) as described by Böyum [9]. Cells harvested from the interface were washed three times in $\mathrm{Ca}$ - and $\mathrm{Mg}$-free Hank's balanced salt solution (Grand Island Biochemical Company [GIBCO], Grand Island, New York). Cells $\left(4 \times 10^{6}\right.$ cells $\mathrm{ml}$ ) were resuspended in RPMI-1640 medium supplemented with $10 \%$ heat-inactivated fetal calf serum, $2.5 \mathrm{mmol} / 1$ HEPES buffer $(\mathrm{GIBCO}), 100 \mathrm{U} / \mathrm{ml}$ penicillin and $100 \mu \mathrm{g} / \mathrm{ml}$ streptomycin (GIBCO). Non-T mononuclear cells were enriched by depletion of $\mathrm{T}$ cells using 16-h E-rosetting. Rosette-forming cells were separated using Ficoll-Hypaque centrifugation. Non-T mononuclear cells obtained from the interface were washed three times and resuspended in the incubation medium.

\section{Target Cell Preparation}

Inbred Wistar-Furth (RTI") or Lewis $\left(\mathrm{RTI}^{1}\right)$ rat islets were isolated using collagenase and purified by centrifugation and visual selection as described previously [10]. Lymph node contamination was avoided by using tangential white light and a black background during visual selection. Target cells were prepared by a modification of a technique described previously [11]. In brief, purified intact islets were incubated at $37^{\circ} \mathrm{C}$ for $1-2$ days in Dulbecco's Modified Eagles Medium (DMEM) and $10 \%$ fetal calf serum under $5 \% \mathrm{CO}_{2}$ and $95 \%$ humidified air. Individual intact islets were visually removed (no acinar debris or lymph nodes present) and dispersed into a single cell suspension by incubation in $200 \mu \mathrm{g} / \mathrm{ml}$ DNAase I (Sigma) in Swim's low calcium medium (GIBCO) containing $1 \mathrm{mmol} / 1$ EGTA (Sigma) and $1 \%$ bovine serum albumin (Miles Laboratories, Kankakee Illinois). The dispersed cells $\left(2-3 \times 10^{6}\right)$ were washed, placed in $250 \mu$ DMEM with $10 \%$ fetal calf serum and incubated with ${ }^{51} \mathrm{Cr}(50 \mu \mathrm{l}$ sodium chromate, $1 \mathrm{mCi} / \mathrm{ml}$, New England Nuclear, Cambridge, Massachussetts) at $37^{\circ} \mathrm{C}$ for $30 \mathrm{~min}$. After washing, the Cr-labelled islet target cells, contained $2500-4000 \mathrm{cpm}$ per $10^{4}$ cells and $>90 \%$ viability was shown by Trypan blue exclusion. Mean \pm SEM islet target cell spontaneous ${ }^{51} \mathrm{Cr}$ release was $16 \pm 0.4 \%(n=28)$ at $4 \mathrm{~h}$ and $21 \pm 0.6(n=36)$ at $8 \mathrm{~h}$, where $n$ includes experiments performed on separate days using separately prepared effector and target cells. Wistar-Furth peritoneal macrophage target cells were prepared by repeated collections of peritoneal washings from normal animals. These cells were incubated with $100 \mu \mathrm{l}^{51} \mathrm{Cr}$ for $2 \mathrm{~h}$ at $37^{\circ} \mathrm{C}$ and after washing, they contained approximately $2000 \mathrm{cpm} / 10^{4}$ peritoneal cells. Spontaneous ${ }^{51} \mathrm{Cr}$ release was $19 \pm 2 \%(n=3)$ at $4 \mathrm{~h}$ and $35 \pm 3 \%(n=3)$ at $8 \mathrm{~h}, n$ representing separate experiments as described above.

\section{Rabbit Anti-Rat Islet Cell Antisera and Antibody Preparation}

Wistar-Furth dispersed islet cells $\left(10^{6}\right)$ were injected into popliteal lymph nodes of anaesthetized New Zealand rabbits and complete Freund's adjuvant used as described previously [12]. Booster intravenous injections of $10^{6}$ islet cells were administered at 2-week intervals. Adsorption studies were performed using rabbit serum $(1 \mathrm{ml})$ incubated with $3 \times 10^{7}$ Wistar Furth spleen cells for $1 \mathrm{~h}$ at room temperature followed by overnight adsorption at $4^{\circ} \mathrm{C}$ [13]. Immune and normal rabbit $\mathrm{IgG}$ was isolated from serum using ammonium sulphate fractionation and DEAE-cellulose anion exchange chromatography as described previously [14].

\section{Cytotoxicity Assays}

Triplicate tubes contained DMEM, $10 \%$ fetal calf serum and $10^{4}$ serum- or antibody-coated islet target cells and, in all but the C'AMC assay, variable quantities of effector cells. Incubations were from $1-8 \mathrm{~h}$ at $37^{\circ} \mathrm{C}$ under $5 \% \mathrm{CO}_{2}$ and $95 \%$ humidified air. ${ }^{51} \mathrm{Cr}$-labelled target cells were coated by incubating various dilutions of heat inactivated rabbit anti-rat islet cell serum, normal rabbit serum or purified immune or normal IgG preparations with $1-5 \times 10^{5}$ islet target cells at $37^{\circ} \mathrm{C}$ for $30 \mathrm{~min}$ in $1.8 \mathrm{ml}$ polypropylene tubes. Excess serum or IgG was removed by centrifugation at $11,600 \times \mathrm{g}$ for $15 \mathrm{~s}$ and target cells were washed twice with $1 \mathrm{ml}$ DMEM containing $10 \%$ fetal calf serum. For C'AMC, target cells were coated with heat-inactivated serum or IgG and incubated with 5\% (final concentration) fresh normal rabbit serum (exogenous complement source). Similarly prepared tubes containing heat-inactivated $5 \%$ normal rabbit serum (complement-inactivated) were used for spontaneous ${ }^{51} \mathrm{Cr}$ release estimates. For cell-mediated cytotoxicity, non-T mononuclear cells from normal control subjects were used, and ${ }^{51} \mathrm{Cr}$ spontaneous release was determined from tubes without added mononuclear cells. For ADCC, non- $T$ mononuclear cells from normal subjects were added to incubation tubes containing heat-inactivated immune or normal rabbit serum or purified immune or normal IgG. Spontaneous ${ }^{51} \mathrm{Cr}$ release for $\mathrm{ADCC}$ was determined from tubes containing rabbit anti-rat islet cell serumcoated islet target cells but no mononuclear cells. For C'ADCC assays, procedures were as described for $\mathrm{ADCC}$ except that experimental tubes contained $5 \%$ fresh normal rabbit serum as a source of complement, and spontaneous ${ }^{51} \mathrm{Cr}$ release estimates were derived from tubes identical to the C'AMC assay which permitted correction for complement-dependent antibody-induced lysis (see below). Be- 


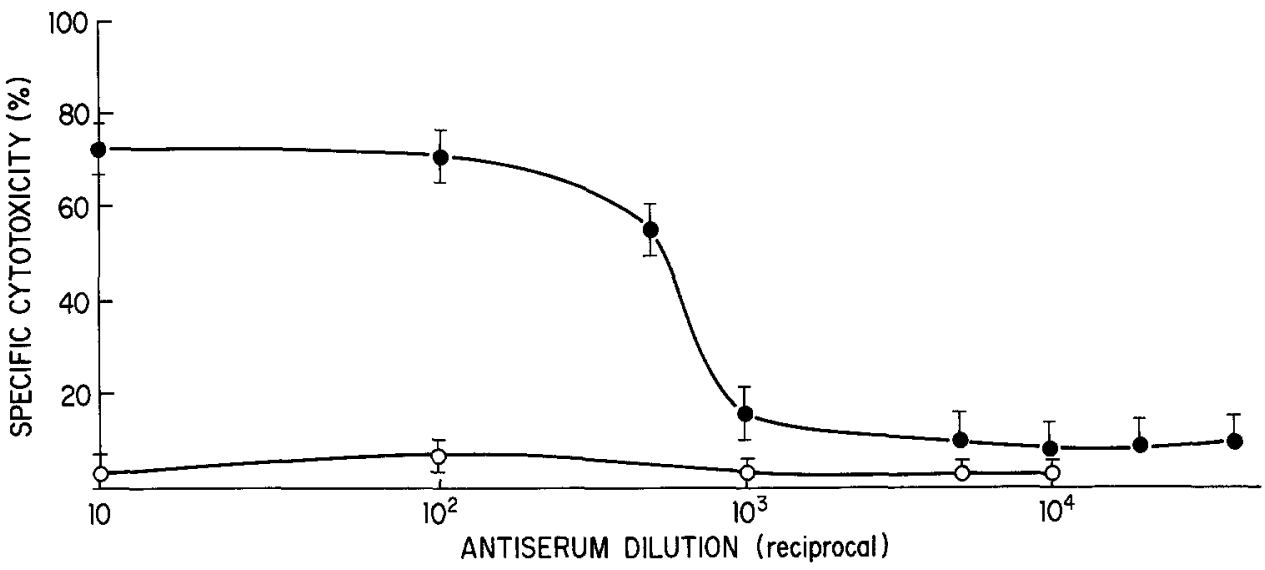

Fig. 3. Complement-dependent antibody-mediated cytotoxicity (C'AMC) for rabbit anti-rat islet cell serum-mediated C'AMC ( $-\mathbf{O})$ and normal rabbit serum $\left(\mathrm{O}_{-} \mathrm{O}\right)$. Data points (mean \pm SEM) are for $n=12$ at dilutions $10,10^{2}$, and $10^{3}$ and $n=8$ at dilutions $0.5,1,20$ and $40 \times 10^{4}$ of rabbit anti-rat islet cell serum. For normal rabbit serum $n=8$ for each data point. (See Fig. 2 for definition of $n$ ). Values at dilutions $5 \times 10^{3}$ were not consistently different from those of control normal rabbit serum mediated C'AMC

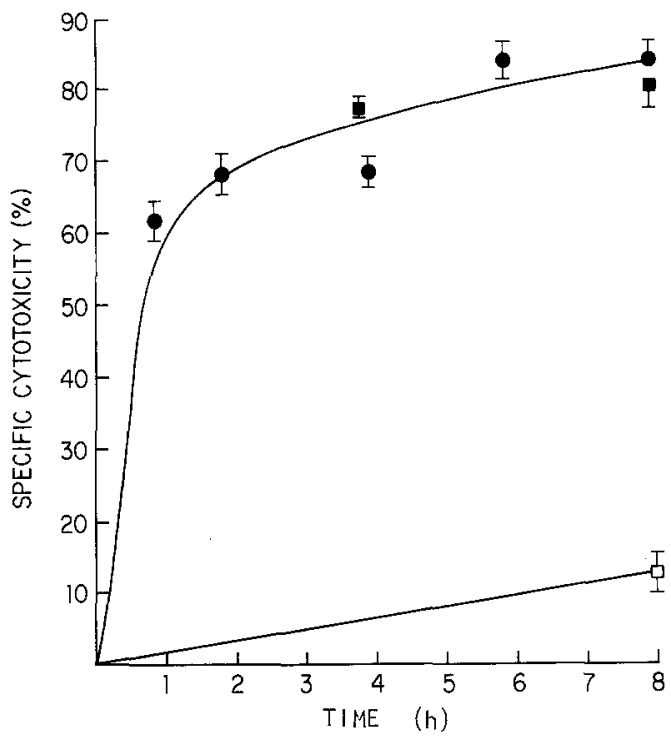

Fig.4. Complement-dependent antibody-mediated cytotoxicity (C'AMC) time course and specificity. Specific ${ }^{51} \mathrm{Cr}$ release by WistarFurth rat islet target cells (-), Lewis rat islet target cells $(\boldsymbol{\square})$ and Wistar-Furth macrophage target cells ( $\square$ ), using rabbit anti-rat islet cell serum at 1:100 dilution. Data represent (mean $\pm \mathrm{SEM}$ ) $n=3$ for Wistar-Furth islet cells at 1,2 and $6 \mathrm{~h}, n=6$ for 4 and $8 \mathrm{~h}$, and for Lewis islet target cells $n=12$ at 6 for 4 and $8 \mathrm{~h}$, respectively. For macrophage target cells $n=3$. (see Fig. 2 for definition of $n$ )

fore and after incubations for C'AMC, cell mediated cytotoxicity, ADCC or C'ADCC, the tubes were mixed, centrifuged at $11,600 \times \mathrm{g}$ for $15 \mathrm{~s}$ or $2 \mathrm{~min}$, respectively. Supernatants and pellets were assessed for radioactivity. Calculations were based on cytotoxicity equivalent to experimental ${ }^{51} \mathrm{Cr}$ released minus spontaneous ${ }^{51} \mathrm{Cr}$ released divided by maximal ${ }^{51} \mathrm{Cr}$ released (Triton $\mathrm{X}$ ) minus spontaneous ${ }^{51} \mathrm{Cr}$ released [15]. Triton $\mathrm{X}$ releases $97 \%-100 \%$ of ${ }^{51} \mathrm{Cr}$ bound by islet cells and $88 \%-92 \%$ bound by macrophage cells. For ADCC and C'ADCC assays, cell mediated cytotoxicity was subtracted from the apparent ADCC and C'ADCC values calculated as described above. Cell mediated cytotoxicity at $4 \mathrm{~h}$ incubations ranges from $12 \%-21 \%$ specific cytotoxicity. These calculations corrected for cytotoxicity related to direct cell-mediated killing. Thus, the effects of immune sera, IgG, complement and effector cells are each corrected prior to the final ADCC or C'ADCC expression. The within and between assay variation was $7 \%$ and $16 \%$ respectively. Lymphocytotoxicity assays were performed by standard methods using guinea pig complement [16].

\section{Statistical Analysis}

All data are presented as mean \pm SEM. Specific cytotoxicity expressions were compared using the unpaired Student's t-test.

\section{Results}

\section{${ }^{51}$ Cr Dispersed Islet Target Cell Labelling}

${ }^{51} \mathrm{Cr}$ islet cell uptake was rapid, and sufficient radioactivity was incorporated by $30 \mathrm{~min}$ to permit islet cell cytotoxicity evaluations (Fig.1). Islet cell spontaneous ${ }^{51} \mathrm{Cr}$ release was of low magnitude permiting 2,4 or $8 \mathrm{~h}$ assay incubations (Fig. 2).

\section{Direct Rabbit Anti-Rat Islet Cell Antiserum-Mediated Cytotoxicity}

To determine whether immune rabbit serum was directly toxic to islet target cells in the absence of complement, heat-inactivated rabbit anti-rat islet cell serum was coated to islet cells at dilutions of $1: 1,1: 10,1: 100$, $1: 1000$. At $1: 1$ and $1: 10$, specific cytotoxicity was $20 \%$ and $10 \%$, respectively, but this effect was absent at dilutions greater than 1:20. Normal rabbit serum did not mediate islet cell lysis. Immunoglobulin $\mathrm{G}$ prepared from rabbit anti-rat islet cell serum or normal rabbit serum at islet coating concentrations of $10,50,100,500$ and $1000 \mu \mathrm{g} / \mathrm{ml} \mathrm{did} \mathrm{not} \mathrm{affect} \mathrm{antibody-mediated} \mathrm{cyto-}$ toxicity in the absence of complement (data not shown).

\section{Complement-Dependent Antibody-Mediated Cytotoxicity}

To determine whether rabbit anti-rat islet cell serum mediated C'AMC, islets were coated with various dilutions of immune or normal rabbit serum and incubated for 1-8 h (Figs. 3 and 4). C'AMC cytotoxicity was maximal at $1: 10$ and $1: 100$ dilutions and mean half-maximal C'AMC occurred at a dilution of 1:800. Rabbit anti-rat islet cell serum was significantly more cytotoxic to islet cells than macrophage target cells, and neither normal rabbit serum, nor normal rabbit serum containing active complement, mediated islet C'AMC (Figs.3 and 4). That C'AMC is dependent on the complement concentration is shown in Fig. 5. To determine whether rabbit anti-rat islet cell serum mediated killing via islet major histocompatibility complex antigens, two indirect experiments were performed. Immune sera-mediated C'AMC was observed to be less with macrophage target 


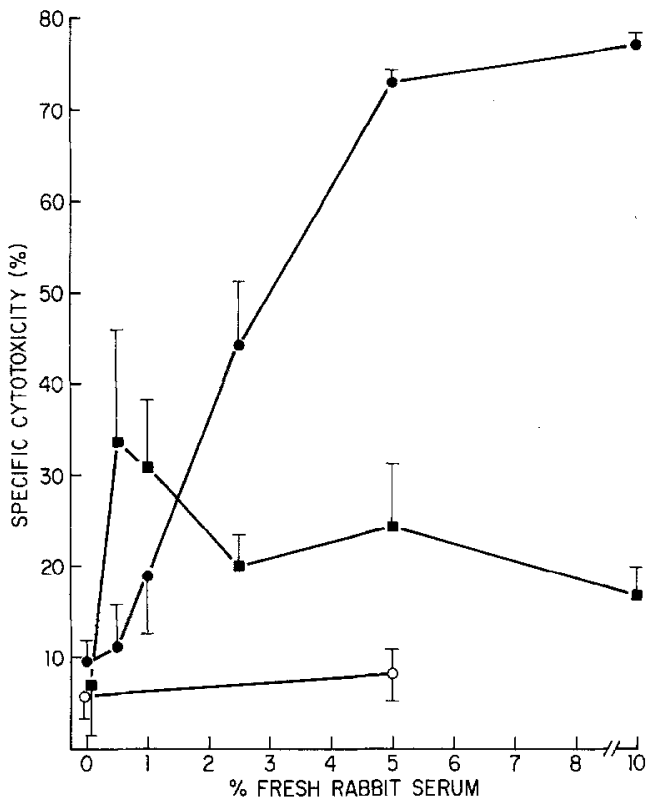

Fig.5. Complement dependence for complement-dependent antibody-mediated cytotoxicity (C'AMC) and complement-mediated antibody-dependent cellular cytotoxicity ( $\left.C^{\prime} A D C C\right)$. Various concentrations of fresh rabbit serum (complement source) were added to C'AMC assays $(n=4)$ at a $1: 10$ dilution of rabbit anti-rat islet cell serum (-). Similar experiments were performed for C'ADCC $(n=4)$ at an immune serum dilution of $1: 1000$ and a 1:40 targeteffector ratio ( $\square$ ). Control experiments $(n=3)$ were performed using fresh serum (complement) in the absence of immune serum $(\mathrm{O}-\mathrm{O})$

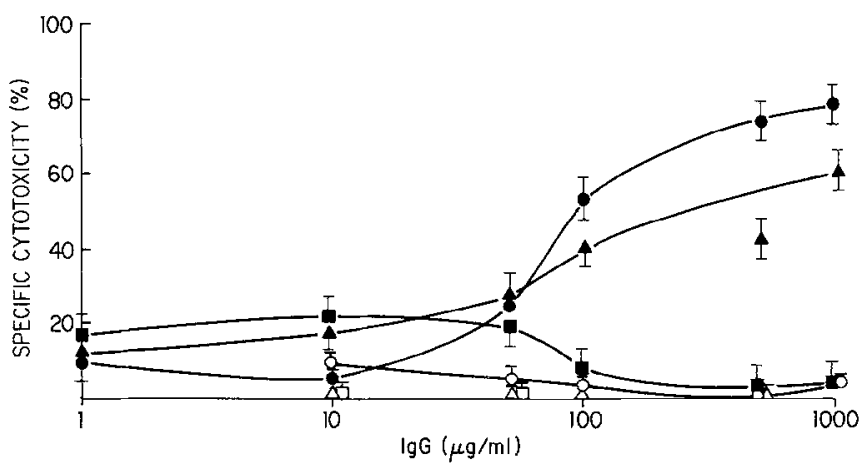

Fig. 6. Purified IgG-mediated cytotoxicity mechanisms. Islet cells were coated with purified IgG and washed before incubation with effector systems. Rabbit anti-rat islet cell antiserum-mediated complement-dependent antibody-mediated cytotoxicity (C'AMC, $n=7$ ), antibody-dependent cellular cytotoxicity (ADCC, $\mathbf{\Lambda}$, $n=5$ ) and complement-augmented antibody-dependent cellular cytotoxicity (C'ADCC, $\square, n=4$ ) $\bigcirc-O, \triangle-\triangle, \square-\square$ represent normal rabbit serum-mediated C'AMC $(n=4), \operatorname{ADCC}(n=3)$, and C'ADCC $(n=2)$, respectively

cells than islets and both Wistar-Furth and Lewis islet target cells were lysed to a similar extent (Fig. 4). Secondly, an aliquot of rabbit anti-rat islet cell serum was doubly adsorbed using Wistar-Furth spleen cells and $<10 \%$ inhibition of C'AMC against islet target cells was observed, whereas $>80 \%$ lymphocytotoxicity mediated by unadsorbed serum was completely inhibited (Table 1). To determine if this C'AMC was related to
Table 1. Lymphocytotoxicity of rabbit anti-rat islet cell serum before and after Wistar-Furth spleen cell adsorption

\begin{tabular}{|c|c|c|c|c|c|c|}
\hline \multirow{2}{*}{$\begin{array}{l}\text { Antiserum } \\
\text { treatment }\end{array}$} & \multirow[t]{2}{*}{ Undiluted } & \multicolumn{5}{|c|}{ Dilution } \\
\hline & & $1 / 2$ & $1 / 4$ & $1 / 8$ & $1 / 16$ & $1 / 32$ \\
\hline Unadsorbed & $8^{\mathrm{a}}$ & 8 & 8 & 6 & 2 & 1 \\
\hline One adsorption & 4 & 1 & 0 & 0 & 0 & 0 \\
\hline Two adsorptions ${ }^{b}$ & 1 & 1 & 0 & 0 & 0 & 0 \\
\hline
\end{tabular}

IgG antibody, rabbit anti-rat islet cell serum- and normal rabbit serum-derived IgG were prepared. Figure 6 shows that rabbit anti-rat islet cell serum-derived IgG mediated maximal and half maximal C'AMC at 500 and $50 \mu \mathrm{g} / \mathrm{ml}$ respectively, whereas normal rabbit serum-derived $\mathrm{IgG}$ did not mediate C'AMC.

\section{Antibody-Dependent Cellular Cytotoxicity}

To determine whether immune islet serum mediated ADCC, rabbit anti-rat islet cell serum coated target cells at dilutions of $1: 10$ to $1: 40,000$ were incubated with human non-T mononuclear cells for 4 or $8 \mathrm{~h}$ at target cell: effector cell ratios of $1: 10$ to $1: 100$. As shown in Fig. 7, rabbit anti-rat islet cell serum mediates ADCC at dilutions of 1:10-1:5000. The optimal target cell: effector cell ratio was $1: 100$, however, significant ADCC was observed always at $1: 40$ whereas at $1: 10$ or $1: 20$, inconsistent ADCC was noted. Incubations for 4 or $8 \mathrm{~h}$ showed similar ADCC responses at 1:40 target cell: effector cell ratios. Total cytotoxicity was less at $4 \mathrm{~h}$ than at $8 \mathrm{~h}$, but after correction for direct cell-mediated cytotoxicity, ADCC was similar at both time periods. Maximal ADCC occurred at an antibody dilution of $1: 10$, and half-maximal ADCC at 1:300 dilution. To determine ADCC specificity to islet cells, rat macrophage target cells were used and the cytotoxicity was $10.5 \pm$ $2.7 \%$ at a $1: 10$ immune serum dilution and $1: 40$ target cell: effector cell ratio whereas for islet target cells cytotoxicity was $51 \pm 5.1 \%$. When rabbit anti-rat islet cell serum-derived IgG was coated to islet target cells, maximal and half-maximal ADCC induced by IgG occurred at approximately 200 and $50 \mu \mathrm{g} / \mathrm{ml} \mathrm{IgG} \mathrm{concentrations,}$ respectively, whereas normal rabbit serum-derived IgG did not mediate ADCC (Fig. 6).

\section{Complement-Augmented Antibody-Dependent Cellular Cytotoxicity}

To determine whether rabbit immune serum mediated C'ADCC, rabbit anti-rat islet cell serum-coated target cells were incubated with human non-T mononuclear cells and complement at immune serum dilutions of $1: 10-1: 40,000$ for $4 \mathrm{~h}$ and at target cell: effector cell ratios of $1: 10-1: 100$ (Fig. 8). Four or $8 \mathrm{~h}$ incubation periods resulted in similar C'ADCC results. A target: 

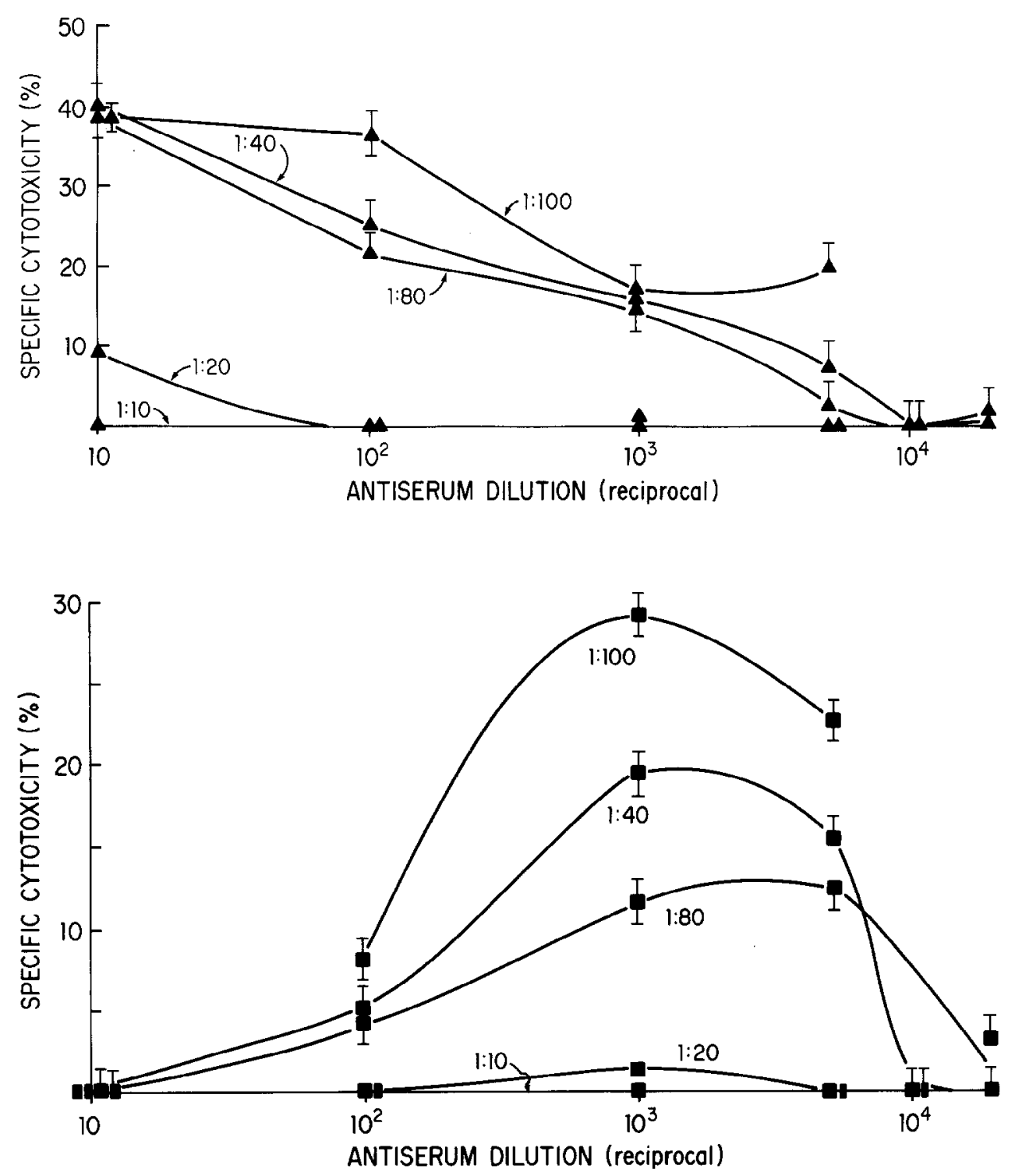

Fig. 7. Rabbit antibody model for antibody-dependent cellular cytotoxicity (ADCC). Human non-T mononuclear cells were used as effector cells at target: effector cell ratios indicated by arrows. Incubations were for $4 \mathrm{~h}$ with rabbit anti-rat islet cell serum. Each data point represents at least $n=3$
Fig. 8. Rabbit antibody model for complement-mediated antibodydependent cellular cytotoxicity (C'ADCC). Human non-T mononuclear cells were used as effector cells at target: effector ratios indicated by arrows. Incubations were for $4 \mathrm{~h}$ with rabbit anti-rat islet cell serum. Each data point represents at least $n=4$ effector ratio of 1:100 was optimal for C'ADCC. The effect of increasing complement concentrations on C'ADCC is shown in Fig. 5. Specificity of C'ADCC to islet cells was shown using macrophage target cells which were not killed at 1:1000 dilution and 1:40 target cell: effector cell ratio, whereas using islet target cells cytotoxicity was $25.6 \pm 7.1 \%$. The strategy for the C'ADCC assay included variables which were corrected by subtracting both the cellular and C'AMC effects from the total cytotoxicity (see Methods). At high cytotoxic levels of C'AMC or ADCC, C'ADCC is difficult to document since C'AMC is nearly $80 \%-90 \%$ and direct cell-mediated cytotoxicity adds additional lysis. Thus, at dilutions of rabbit anti-rat islet cell serum 1:10 or 1:100, C'ADCC is of low magnitude whereas at dilutions which are associated with minimal C'AMC and ADCC, C'ADCC is observed. It is clear that complement can augment ADCC at a dilution of immune serum insufficient to mediate C'AMC or ADCC (Fig.9). Expression of maximal and half maximal rabbit anti-rat islet cell serum-mediated C'ADCC was 1:1000 and
$1: 5000$ at a target effector ratio of $1: 40$. As shown in Fig. 6, rabbit anti-rat islet cell serum-derived IgG mediated C'ADCC with expression of maximal and halfmaximal cytotoxicity at $<100$ and $1 \mu \mathrm{g} / \mathrm{ml}$ respectively, whereas normal rabbit serum-derived $\mathrm{IgG}$ did not mediate C'ADCC.

\section{Discussion}

Since the pathogenesis of Type 1 diabetes may be mediated by cytotoxic immune phenomena, in vitro assays capable of quantitating these mechanisms would be useful. Thus, we developed an islet target cell cytotoxicity model which characterizes assay specificity, sensitivity, incubation conditions and most importantly demonstrates multiple antibody-mediated cytotoxic mechanisms. Using this model, rabbit anti-rat islet cell serum was shown to mediate not only C'AMC but also, in collaboration with human non-T mononuclear cells, to mediate ADCC and C'ADCC. Since each of these mechanisms could be involved in the pathogenesis of insulin- 


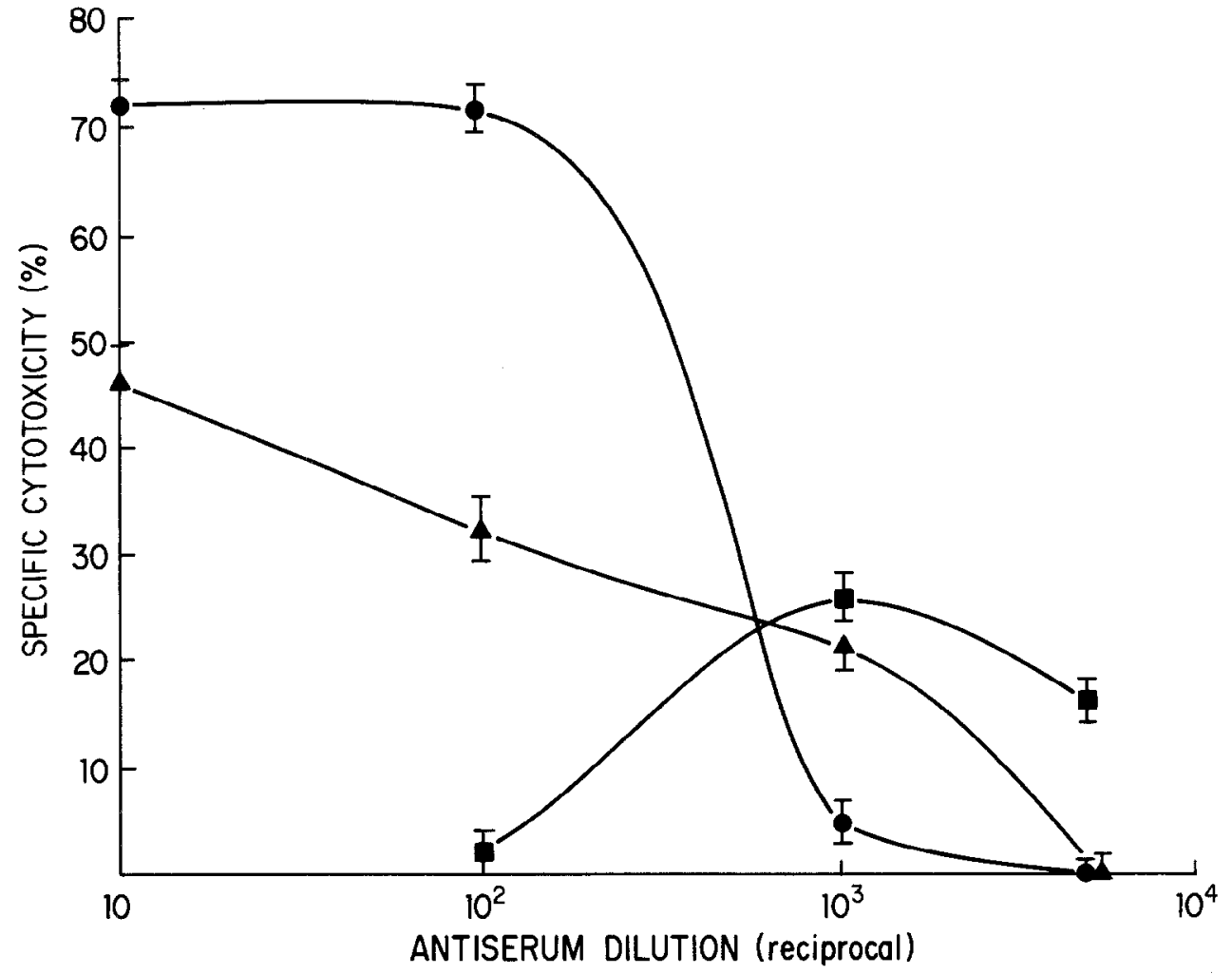

Fig.9. Rabbit anti-rat islet cell serum-mediated cytotoxicity mechanisms: complement-dependent antibody-mediated toxicity (C'AMC, ), antibody-dependent cellular cytotoxicity (ADCC, $\mathbf{\Lambda}-\mathbf{\Lambda})$ and complement-mediated antibody-dependent cellular cytotoxicity $\left(C^{\prime} A D C C,-\mathbf{a}\right)$. Each data point represents at least $n=3$. These experiments illustrate the presence of C'ADCC at 1:5000 dilution in the absence of C'AMC and ADCC dependent diabetes, these assays were further evaluated.

Normal non-cultured dispersed rat islet cells permit a maximal normal islet $\beta$ cell population (70\%-80\%), which can be produced on a regular basis from several rodent species and man, and thus can be used in conjunction with ${ }^{51} \mathrm{Cr}$ labelling to study conventional antibody-mediated cytotoxic mechanisms. We have not directly shown that islet $\beta$ cells are killed in our cytotoxicity assay system, but since triton $\mathrm{X}$ releases approximately $97 \%-100 \%$ of islet-incorporated ${ }^{51} \mathrm{Cr}, 85-90 \%$ isletspecific C'AMC suggests that $\beta$ cells are the major target cell type evaluated in these assays assuming all islet cells have similar ${ }^{51} \mathrm{Cr}$ uptake. Recent results from other laboratories also suggest islet $\beta$ cell killing in cultured islet target cell systems $[3,6]$.

Other variables also exist for complement-dependent antibody-mediated cytotoxicity assays, such as cross-reactivity between human antibodies and rodent islet $\beta$ cells. Both antibody islet cell binding and cytotoxic cross-reactivities have been well-documented $[4-7,17]$. Although the pathogenic relationships of islet cell antibody binding and cytotoxicity remain unclear, one recent report describes monoclonal antibodies, some of which bind only rat islet tumour cells, whereas others are also cytotoxic [18].

Specific C'AMC was shown using the rabbit anti-rat islet cell serum model antibody system. Similar observations have been reported using human sera derived from insulin-dependent diabetic patients [4-7], however, DEAE-purified IgG has not been investigated. Our studies directly show that C'AMC is mediated by the IgG fraction of the rabbit antisera. Since we show also that this antiserum has non-IgG-mediated cytotoxic effects at high concentrations, human sera also should be examined for IgG-mediated cytotoxicity.

Our studies suggest that rabbit anti-rat islet cell serum-induced C'AMC is not related to islet major histocompatibility antigens since rabbit immune sera was equally effective against islet cells of different RTl classes (Wistar-Furth and Lewis) but was less effective against rat macrophage target cells. Since other cell types have not yet been examined these conclusions should be considered preliminary. After adsorption using Wistar-Furth spleen cells, the rabbit antisera remained cytotoxic to islet cells despite the abolition of lymphocytotoxicity. The lymphocyte and macrophage cytotoxicity initially present could be related to passenger immune cells present in islet cell preparations and/or MHC antigens on islet cells [19].

Islet ADCC mechanisms have not been reported previously although insulin-dependent patients are described to have increased numbers of $\mathrm{K}$ cells and increased $\mathrm{K}$ cell cytotoxicity against non-islet target cells $[20,21]$. Others have predicted ADCC to be an important mechanism in the pathogenesis of diabetes [1]. We have reported preliminary data of ADCC in insulin-dependent diabetic patients [4]. Some normal subjects' mononuclear cells did not mediate $\mathrm{ADCC}$ at target cell: effector cell ratios of $1: 10$ and $1: 20$; but in these earlier studies we used target:effector cell ratios that were too low as indicated by the present data. The finding of rabbit anti-rat islet cell serum-mediated ADCC in the current study serves as a positive control for the gen- 
eral absence of ADCC in sera derived from insulin-dependent diabetic patients reported in our subsequent studies $[8,22]$.

Complement-augmented ADCC has been described in model systems and it has been suggested that complement enhances binding of cellular effectors to antibody-bound target cells [23-25]. The relevance of C'ADCC mechanisms to disease pathogenesis is unclear. The relevance of C'ADCC to insulin-dependent diabetes is suggested by our recent observations in humans [8, 22], and our documentation that human effector cells can effectively collaborate with antibody and complement to kill islet cells. For ADCC and C'ADCC, DEAE-purified IgG was shown to mediate islet cell cytotoxicity, thus eliminating non-specific serum toxic factors as a potential mechanism.

The nature of the cytotoxic reactivities expressed by the three antibody mechanisms studied suggests that (a) each antibody mechanism has a unique minimum serum dilution for maximal cytotoxicity expression, i.e., $1: 100$ for C'AMC, $1: 10$ for ADCC, and $1: 1000$ for C'ADCC, (b) each antibody mechanism has a unique half-maximal immune serum dilution for cytotoxicity expression, i.e., 1:800 for C'AMC, 1:300 for ADCC and 1:5000 for C'ADCC and (c) although C'AMC shows the greatest capacity for islet cell lysis, C'ADCC appears to be the most sensitive cytotoxic mechanism. Since cellular infiltrates are observed in recent onset insulin-dependent diabetic patients' islets, cellular mechanisms in collaboration with antibody (ADCC or C'ADCC), or cellular mechanisms alone, may be important pathogenic factors. The relative roles of C'AMC, ADCC and C'ADCC with respect to insulindependent diabetes can be evaluated in detail using the in vitro assay systems described.

Acknowledgements. The authors thank S. Burns for preparation of the manuscript. We are also indebted to J. Liu for technical assistance.

\section{References}

1. Nerup J, Lernmark A (1981) Autoimmunity in insulin-dependent diabetes. Am J Med 70: 135-141

2. Cahill GF Jr, McDevitt HO (1981) Insulin-dependent diabetes mellitus: the initial lesion. N Engl J Med 304: 1454-1465

3. Huang SW, Maclaren HO (1976) Insulin-dependent diabetes: a disease of autoaggression. Science 192: 64-66

4. Charles A, Sharma B, Waldeck N, Dodson E, Noble S (1979) Use of in vitro cytotoxicity assays for the direct evaluation of immune mechanispus in diabetic patients. Diabetes 28: $397 \mathrm{~A}$

5. Rittenhouse HG, Oxender DL, Pek S, Ar D (1980) Complementmediated cytotoxic effects on pancreatic islets with sera from diabetic patients. Diabetes 29: 317-322

6. Dobersen MJ, Scharff JE, Ginsberg-Fellner F, Notkins AL (1980) Cytotoxic autoantibodies to beta cells in the serum of patients with insulin-dependent diabetes mellitus. N Engl J Med 303: 1493-1498

7. Eisenbarth GS, Morris MA, Scearce RM (1981) Cytotoxic antibodies to cloned rat islet cells in serum of patients with diabetes mellitus. J Clin Invest 67: 403-408

8. Charles MA, Suzuki M, Waldeck N, Dodson LE, Ong K, Kersh- nar A, Buckingham B, Golden M (1983) Immune islet killing mechanisms associated with insulin-dependent diabetes: the expression of cellular and antibody-mediated islet cell cytotoxicity mechanisms in humans. J Immunol 130: 1189-1194

9. Böyum A (1976) Isolation of lymphocytes, granulocytes and macrophages. Scand J Immunol 5:9-15

10. Charles MA, Lawecki J, Pictet R, Grodsky GM (1975) Insulin secretion: interrelationships of glucose, cyclic adenosine $3^{\prime}, 5^{\prime}$ monophosphate, and calcium. J Biol Chem 250: 6134-6140

11. Lernmark A (1974) The preparation of, and studies on, free cell suspensions from mouse pancreatic islets. Diabetologia 10: 431-438

12. Lernmark A, Kanatsuna T, Patzelt C, Diakoumis K, Carroll R, Rubenstein AH, Steiner DF (1980) Antibodies directed against the pancreatic islet cell plasma membrane. Detection and specificity. Diabetologia 19: 445-451

13. Shulman NR, Marder VJ, Hiller MC, Collier EM (1964) Platelet and leukocyte isoantigens and their antibodies, serologic, physiologic and clinical studies. Progr. Hematol 4: 222-304

14. Geokas MC (1977) Pancreatic elastase in human serum; determination by radioimmunoassay. J Biol Chem 252: 61-67

15. Leibold W, Gatti RA, Just S, Peter HH (1979) Spontaneous cellmediated cytotoxicity and generation of HLA-unrelated cytotoxic effector cells during MLC in vitro. Transplant Proc 11: 1391-1399

16. Terasaki PI, Park MS (November 1979) Microdroplet lymphocyte cytotoxicity test. National Institute of Allergy and Infectious Diseases Manual Tissue Typing Techniques 1979-1980, United States Department of Health, Education and Welfare (NIH Publication No. 80-545)

17. Lernmark A, Freedman ZR, Hofmann C, Rubenstein AH, Steiner DF, Jackson RL, Winter RJ, Traisman HS (1978) Islet-cell-surface antibodies in juvenile diabetes mellitus. N Engl J Med 299: 375-380

18. Eisenbarth GS, Oie H, Gazdar A, Chick W, Schultz JA, Searce RM (1981) Production of monoclonal antibodies reacting with rat islet cell membrane antigens. Diabetes 30: 226-230

19. Faustman D, Hauptfeld V, Davie JM, Lacy PE, Shreffler DC (1980) Murine pancreatic beta cells express H-2K and H-2D but not Ia antigens. J Exp Med 151: 1563-1568

20. Pozzilli P, Sensi M, Gorsuch AN, Bottazzo GF, Cudworth AG (1979) Evidence for raised K-cell levels in Type 1 diabetes. Lancet 2: $173-175$

21. Sensi M, Pozzilli P, Gorsuch AN, Bottazzo GF, Cudworth AG (1981) Increased killer cell activity in Type 1 (insulin-dependent) diabetes. Diabetologia 20: 106-109

22. Suzuki M, Charles A, Ong K, Buckingham B, Kershner A, Slater L, Waldeck N, Wudrick R (1981) In vitro islet cell cytotoxocity assays for evaluation of potential cellular and antibody-mediated immunologic mechanisms in diabetic patients Diabetes (Suppl 1) 30: $56 \mathrm{~A}$

23. Lustig HJ, Bianco C (1976) Antibody-mediated cell cytotoxicity in a defined system. Regulation by antigen, antibody, and complement. J Immunol 116: 250-260

24. Perlmann P, Perlmann H, Müller-Eberhard HJ (1975) Cytolytic lymphocytic cells with complement receptor in human blood. Induction of cytolysis by IgG antibody but not by target cell-bound C3. J Exp Med 141: 287-296

25. Ghebrehiwet B, Medicus RG, Müller-Eberhard HG (1979) Potentiation of antibody-dependent cell-mediated cytotoxicity by target cell-bound C3 b. J Immunol 123: 1285-1288

Received: 6 December 1982

and in revised form: 26 April 1983

Dr. M.A.Charles

Department of Medicine

Medical Sciences I, Room C240

University of California

Irvine, CA 92717

USA 